\title{
Effects of Progesterone and 17 $\beta$-Estradiol under Presence or Absence of FBS on Plasminogen Activators Activity in Porcine Uterine Epithelial Cells
}

\author{
Yong Hwangbo ${ }^{1, *}$, Mi-Rim Lee ${ }^{1,2, *}$, Hee-Tae Cheong ${ }^{3}$, Boo-Keun Yang ${ }^{1}$, and ${ }^{\dagger}$ Choon-Keun Park ${ }^{1}$ \\ ${ }^{1}$ College of Animal Life Sciences, Kangwon National University, Chuncheon 24341, Korea \\ ${ }^{2}$ Maria Fertility Hospital, Goyang 10387, Korea \\ ${ }^{3}$ College of Veterinary Medicine, Kangwon National University, Chunchoen 24341, Korea
}

\begin{abstract}
The present study was conducted to investigate the regulatory mechanism of plasminogen activators (PAs) activation by $17 \beta$-estradiol $\left(\mathrm{E}_{2}\right)$ and progesterone $\left(\mathrm{P}_{4}\right)$ in porcine uterine epithelial cells (pUECs). pUECs were collected from porcine uterine horn and cultured at $80 \%$ confluence. Then, $0.1 \%(\mathrm{v} / \mathrm{v}) \mathrm{DMSO}, 20 \mathrm{ng} / \mathrm{mL} \mathrm{E}_{2}$, and $\mathrm{P}_{4}$ with or without fetal bovine serum (FBS) treated to cultured cells for 24 hours. The supernatants were used for measurement of PAs activity and expression of urokinase-type PA $(u P A)$, tissue-type PA $(t P A)$, uPA specific receptor $(u P A R)$, and type-1 PA inhibitor (PAI-1) mRNA were analyzed by real-time PCR. The expression of PAs-related genes was not affect by steroid hormones in both of serum treatment groups. However, PAs activity was increased by treatment of $\mathrm{E}_{2}$ compared to $0.1 \%$ DMSO treatment in serum-free group ( $p<0.05)$. Then, $\mathrm{E}_{2}$ and $\mathrm{P}_{4}$ were diluted with $0.002 \%(\mathrm{v} / \mathrm{v})$ DMSO for reduction of its effect and treated to cultured cells without FBS. Only $t P A$ mRNA was significantly increased by $\mathrm{E}_{2}$ treatment $(p<0.05)$. PAs activity was enhanced in $\mathrm{E}_{2}$ treated group compared to control groups $(p<0.05)$. These results indicate that serum-free condition is more proper to evaluate effect of steroid hormones and activation of PAs in pUECs was mainly regulated by estrogen. These regulation of PAs activation may be associated with uterine remodeling during pre-ovulatory phase in pigs, however, further studies are needed to investigate precise regulatory mechanism.
\end{abstract}

Key words : $17 \beta$-estradiol, Progesterone, Plasminogen activators, Uterine epithelial cells, Fetal bovine serum

\section{INTRODUCTION}

As one of important female reproductive tracts, the uterus plays a role in variety of reproductive phenomena including embryo development, implantation, and pregnancy. They undergo physiological alterations including cytokines secretion, gene expression, angiogenesis, increase of number of secretory glands and thickness of endometrium during the estrous cycles (Stroband et al., 1986; Baker et al., 1998; Demir et al., 2010; Franczak et al., 2013). It secretes a various growth factors, cytokines, hormones, nutrients to regulate intrauterine microenvironment and these tissue remodeling in endometrium, which is induced by gonadotropins, steroid hormones, cytokines, and growth factors, provide a suitable environment in uterus for survival and development of embryo, and successful implantation.

Plasminogen activators (PAs) are one of serine proteases that convert inactivated plasminogen to plasmin and they

Manuscript received October 5, 2018, Received in revised form October 20, 2018, Accepted November 10, 2018

${ }^{\dagger}$ Corresponding Author : Choon-Keun Park, College of Animal Life Sciences, Kangwon National University, Chuncheon 24341, Korea. Tel: +82-33-2508627, E-mail: parkck@kangwon.ac.kr

${ }^{*}$ These authors contributed equally to this work.

This is an Open Access article distributed under the terms of the Creative Commons Attribution Non-Commercial License (http:// creative-commons.org/licenses/by-nc/3.0) which permits unrestricted non-commercial use, distribution, and reproduction in any medium, provided the original work is properly cited. 
are present as urokinase-type (uPA) and tissue-type (tPA) in extracellular fluids such as follicular fluid (Beers, 1975), uterine and oviductal fluid (Finlay et al., 1983; Kouba et al., 2000), and seminal fluid (Kobayashi et al., 1992). Activated plasmin degrades fibrin, fibronectin, and laminin, and activates other proteases such as collagenases and matrix metalloproteincase to degrade extracellular matrix (ECM). This feature of plasmin was involved in tissue remodeling (Martin \& Arias, 1982), cell migration (Ploplis et al., 1998), activation of growth factors (Menshikov et al., 2006), and angiogenesis (Olofsson et al., 1998). Uterine and oviductal epithelial cells differently secreted twotype of PAs and their specific inhibitor (PAI) during the estrous cycle (Ahn et al., 2009; Hwangbo et al., 2013).

In female reproductive system, estrogen and progesterone play a crucial role in alteration of reproductive tract including uterus and oviduct for successful pregnancy. Estrogen is one of steroid hormones and it is transported from ovary to uterus through blood vessels. Moreover, it is binding to their specific receptors (estrogen receptors, ERs) in membrane or nuclear of inside cells (Elangovan et al., 2011), and this stimulation by estrogen is associated with initiation of estrous, development of reproductive organs, and promotion of uterine development for implantation (Gray et al., 2001). This hormone is existed as estrone, estradiol, and estriol in mammalians. Especially, 17ß-estradiol $\left(E_{2}\right)$, secreted from porcine conceptus at pre-implantation period, regulates physiological conditions of uterine epithelial cells for successful implantation and it is important factor for maternal recognition in pigs (Bazer \& Johnson, 2014).

Progesterone $\left(\mathrm{P}_{4}\right)$ is steroid hormones secreted from corpus luteum. It is closely involved in estrous cycle, regulation of intrauterine environment for implantation and pregnancy, and maintenance of pregnancy (Spencer \& Bazer, 2002). This hormone bind to their specific receptors (progesterone receptors, PRs), which are exist on membrane or inner nucleus, as well as estrogen and sequential action of these steroid hormones is a crucial role in luteolysis and alteration of physiological function in uterus (Spencer et al., 2004). During the pre-ovulatory phase, expression of PRs and ERs in uterine cells is increased by rapidly increased estrogen from ovary and increased concentration of $\mathrm{P}_{4}$ prevent ERs expression via binding with PRs (McCracken, 1980). These studies demonstrated that $\mathrm{E}_{2}$ and $\mathrm{P}_{4}$ are closely associated with regulation of functional and physiological conditions in endometrium as a key regulatory factors.

In human, mice, and cows, a number of studies regarding to express of PAs in uterus had been reported (Casslen \& Astedt, 1983; Sappino et al., 1989; Tanikawa et al., 2009). However, regulation of PAs activity in porcine uterus is still unclear. Therefore, this study was conducted to investigate change of PAs activity and mRNA expression by $\mathrm{P}_{4}$ and $E_{2}$ according presence of absence fetal bovine serum (FBS) condition in porcine uterine epithelial cells (pUECs).

\section{MATERIALS AND METHODS}

\section{Preparation of pUECs and hormones treatment}

A porcine uterus at pre-ovulatory phase (Day 19-20 of estrous cycle) was collected from a local slaughterhouse and transported to the laboratory within $2 \mathrm{~h}$ on ice. The uterus was washed using Hanks' balanced salt solution (HBSS) containing $0.06 \mathrm{~g} / \mathrm{L}$ penicillin $\mathrm{G}$ and $0.1 \mathrm{~g} / \mathrm{L}$ streptomycin sulfate, and it was separated from ovaries and mesometrium. Epithelial cells were isolated from luminal epithelium by gentle stripping with cell scraper and were incubated with Dulbecco's modified Eagle's medium/ nutrient mixture F-12 Ham (DMEM/F-12; Welgene, Gyeongsang-si, Gyeongsangbuk-do, republic of Korea) containing 66 units/mL Type IV collagenase (Worthington Biochemical Corporation, Lakewood, NJ, USA) at $38.5^{\circ} \mathrm{C}$ for 30 min. To remove red blood cells, collected cells were mixed with Tris- $\mathrm{NH}_{4}$ lysis buffer $\left(17.01 \mathrm{mM}\right.$ Trizma ${ }^{\circledR}$ base, 0.14 $\mathrm{M} \mathrm{NH} \mathrm{N}_{4} \mathrm{Cl}$ ) for $2 \mathrm{~min}$ at room temperature, then it were 
centrifuged at 1,500 $\mathrm{g}$ for $5 \mathrm{~min}$. After centrifugation, the cells were washed by HBSS and cultured in phenol redfree DMEM/F-12 (Welgene) supplemented with $10 \%$ (v/v) FBS (Welgene), $0.1 \%(\mathrm{v} / \mathrm{v})$ antibiotic-antimycotic (ABAM; Invitrogen, Carlsbad, CA, USA), $20 \mu \mathrm{g} / \mathrm{mL}$ amphotericin B (Sigma-Aldrich, St. Louis, MO, USA) in 100 $\mathrm{mm}$ culture dishes at $38.5^{\circ} \mathrm{C}$ in a humidified atmosphere with $5 \% \mathrm{CO}_{2}$ until $80 \%$ confluence. Cultured pUECs were sub-cultured in 6-well culture plate at a density of $3 \times 10^{5}$ cells/well until $80 \%$ confluence for treatment. Then, cells were starved in serum-free DMEM/F-12 for 18 to $24 \mathrm{~h}$ and $20 \mathrm{ng} / \mathrm{mL} \mathrm{E}_{2}$ (Sigma-Aldrich) and $\mathrm{P}_{4}$ (Sigma-Aldrich) with dimethyl sulfoxide (DMSO) in with serum or serum-free medium were treated to starved cells for $24 \mathrm{~h}$. A supernatant and cells were collected and stored at $-70^{\circ} \mathrm{C}$ until analysis for PAs activity assay and quantitative real time RT-PCR, respectively.

\section{Extraction of mRNA and cDNA synthesis}

Extraction of RNA from pUECs was carried out using trizol reagent (Takara, Shiga, Kusatsu, Japan) and cDNA was synthesized by PrimeScript ${ }^{\mathrm{TM}} 1^{\text {st }}$ strand cDNA Syn- thesis Kit (Takara) according to manufacturer's instructions. In brief, $1 \mu \mathrm{g}$ of total RNA were incubated with 5 $\mu \mathrm{M}$ Oligo dT primer and $1 \mathrm{mM} d \mathrm{dTP}$ mixture at $65^{\circ} \mathrm{C}$ for $5 \mathrm{~min}$, and it was immediately cooled on ice after incubation. Then, RNA was mixed with 1 units/ $\mu \mathrm{L}$ RNase inhibitor and 10 unit/ $\mu \mathrm{L}$ RTase, and mixture was reacted to synthesize cDNA at $42^{\circ} \mathrm{C}$ for $1 \mathrm{~h}$. Synthesized cDNA was quantified using NanoDrop 2000 (Thermo Scientific Nanodrop, Wilmington, DE, USA) and was diluted concentration at $50 \mathrm{ng} / \mu \mathrm{L}$ for real time PCR.

\section{Quantitative real time RT-PCR}

All of primers used in this study were designed by Primer3 online software (Table 1). Thunderbird SYBR qPCR mix (Toyobo, Osaka, Japan) was used to real time RTPCR and cDNA amplification was performed following three steps: denaturation at $95^{\circ} \mathrm{C}$ for $15 \mathrm{sec}$, annealing at $60^{\circ} \mathrm{C}$ for $30 \mathrm{sec}$, extension at $72^{\circ} \mathrm{C}$ for $30 \mathrm{sec}, 40$ cycles. Relative expression levels of urokinase-type PA $(u P A)$, tissue-type PA $(t P A)$, uPA specific receptor $(u P A R)$, and type-1 PA inhibitor (PAI-1) mRNA were normalized to glyceraldehyde-3-phosphate dehydrogenase $(G A P D H)$ and

Table 1. Primer sequences for real time PCR

\begin{tabular}{clccc}
\hline \hline Gene & \multicolumn{1}{c}{ Primer sequence $\left(5^{\prime} \rightarrow 3^{\prime}\right)$} & Product size $(\mathrm{bp})$ & Annealing temp. & Accession number \\
\hline$u P A$ & $\begin{array}{l}\text { F: TGCATCGAACTGTGGCTGTC } \\
\text { R: GACCGTTCCCCTCAAAGCAG }\end{array}$ & 146 & $60^{\circ} \mathrm{C}$ & NM_213945 \\
\hline$t P A$ & $\begin{array}{l}\text { F: CAGCCGCTGCACTTCAAAAC } \\
\text { R: GTGTACACACCCGGAACGTC }\end{array}$ & 222 & $60^{\circ} \mathrm{C}$ & NM_214054 \\
\hline$u P A R$ & $\begin{array}{l}\text { F: GCACACATGGGAAGGAGGTG } \\
\text { R: CGAGGCACAGGAAGCACATT }\end{array}$ & 214 & $60^{\circ} \mathrm{C}$ & XM_003127198 \\
\hline PAI-1 & $\begin{array}{l}\text { F: CACCGCCTCTTCCACAAGTC } \\
\text { R: ATGCTCAGAGTGTTGCCGTG }\end{array}$ & 149 & $60^{\circ} \mathrm{C}$ & NM_213910 \\
\hline \multirow{2}{*}{$G A P D H$} & $\begin{array}{l}\text { F: CATGGTTCACGCCCATCACA } \\
\text { R: TCCCGCCAACATCAAATGGG }\end{array}$ & 170 & $60^{\circ} \mathrm{C}$ & NM_001206359 \\
\hline
\end{tabular}

$u P A$, Urokinase-type plasminogen activator; $t P A$, Tissue-type plasminogen activator; $u P A R$, Urokinase-type plasminogen activator receptor; $P A I-1$, Type-1 plasminogen activator inhibitor; GAPDH, Glyceraldehyde-3-phosphate dehydrogenase. 
analyzed by $2^{-\Delta \Delta \mathrm{Ct}}$ method.

\section{PAs activity assay}

Samples of the collected culture medium $(20 \mu \mathrm{L})$ were dispensed into a 96-well microplate and mixed with $30 \mu \mathrm{L}$ of a plasminogen working solution $(2.5 \mu \mathrm{g} /$ well plasminogen; Sigma-Aldrich). The solution was incubated at $38^{\circ} \mathrm{C}$ for $1 \mathrm{~h}$. After incubation, $200 \mu \mathrm{L}$ of substrate buffer [0.18 $\mathrm{mM}$ Z-L-Lys-SBzl hydrochloride, $0.22 \mathrm{mM}$ 5,5'-dithiobis(2-nitrobenzoic acid), and $0.01 \%$ Triton X-100] was added and was subsequently incubated at $38^{\circ} \mathrm{C}$ for $1 \mathrm{~h}$. PAs activity was determined by absorbance at the wavelength of 405 $\mathrm{nm}$ using a microplate reader.

\section{Experimental designs}

1) Experiment 1: Alteration of effect of $E_{2}$ and $P_{4}$ on PAs activity according to presence or absence of FBS in culture medium

To compare effect of steroids on PAs expression and activation by FBS, pUECs, which were cultured at $50 \%$ confluence, were starved for 18 to $24 \mathrm{~h}$. Then, they were incubated in culture medium with or without FBS containing $20 \mathrm{ng} / \mathrm{mL} \mathrm{E}_{2}$ or $\mathrm{P}_{4}$ for $24 \mathrm{~h}$. In experiment 1 , both of steroid hormones were diluted with DMSO and final concentration was at $0.1 \%(\mathrm{v} / \mathrm{v})$ DMSO in treatment groups. Because FBS contain several protease inhibitors and plasmin is one of proteases, we compared the pattern of PAs activity and expression with or without FBS. As a control groups, we prepared serum control and serum-free control without DMSO.

2) Experiment 2: Effect of $E_{2}$ and $P_{4}$ on PAs activity in culture medium with reduced concentration of DMSO

Based on results in experiment 1 , we expected that $0.1 \%$ DMSO weakly influenced to expression of PAs-related genes. To identify more precise effect of steroid on PAs activity in pUECs, steroid hormones were diluted with reduced concentration of DMSO $(0.002 \%$; v/v). In experiment 1 , we confirmed that pUECs sensitively response to steroid hormones in FBS absence condition. Thus, only serum-free medium was used in experiment 2 . Concentration and treatment time of hormones were followed to experiment 1 .

\section{Statistical analysis}

All numerical data representing each parameter were analyzed using Statistical Analysis System software (SAS, version 9.4). Data are represented as the means \pm standard error of the mean (SEM). Data from experiment 1 were analyzed using Duncan's multiple range test, and $t$-test was used for experiment 2. Comparisons among treatment groups were conducted using a generalized linear model in the SAS package. A value of $p<0.05$ was considered statistically significant.

\section{RESULTS}

\section{Action of hormones on PAs activity by presence} or absence of FBS in culture medium

The effect of sex steroids, which were diluted with $0.1 \%$ DMSO, in different serum condition on PAs-related genes expression and activation of PAs shown in Figs. 1 and 2. The expression of PAs-related genes were not changed by hormones in both of serum treatment groups. Treatment of $E_{2}$ in serum-free group increased PAs activity compared to $0.1 \%$ DMSO treatment $(p<0.05)$, whereas it was not altered in serum group.

\section{Effect of $\mathrm{E}_{2}$ and $\mathrm{P}_{4}$ on PAs activity in culture me-} dium with reduced concentration of DMSO

Change of PAs mRNA expression and activity by steroid hormones with reduced DMSO concentration shown in Figs. 3 and 4, respectively. Only expression of $t P A$ mRNA was increased by $\mathrm{E}_{2}$ treatment $(p<0.05)$ and $0.002 \%$ 
A

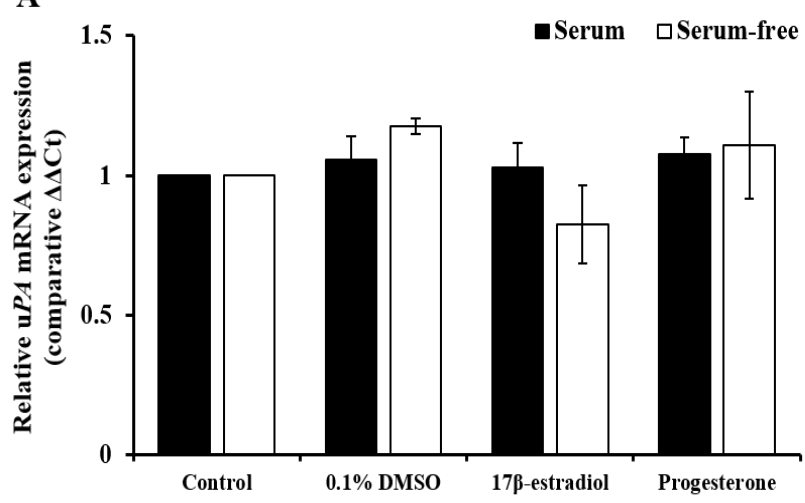

C

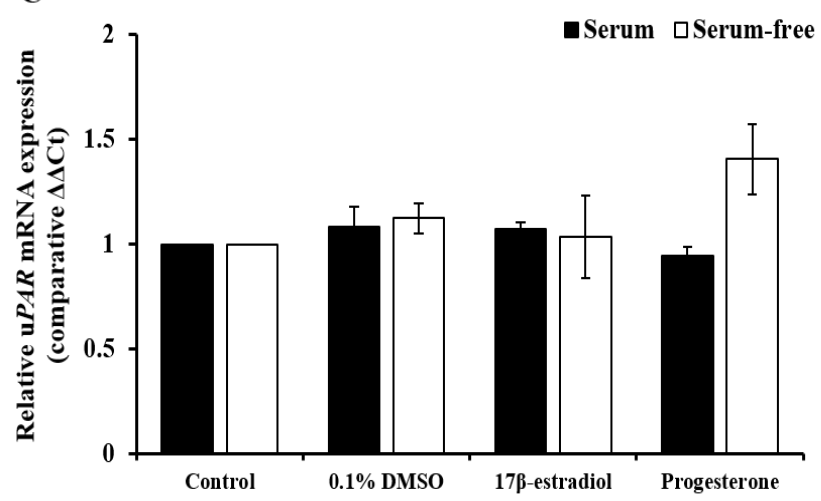

B

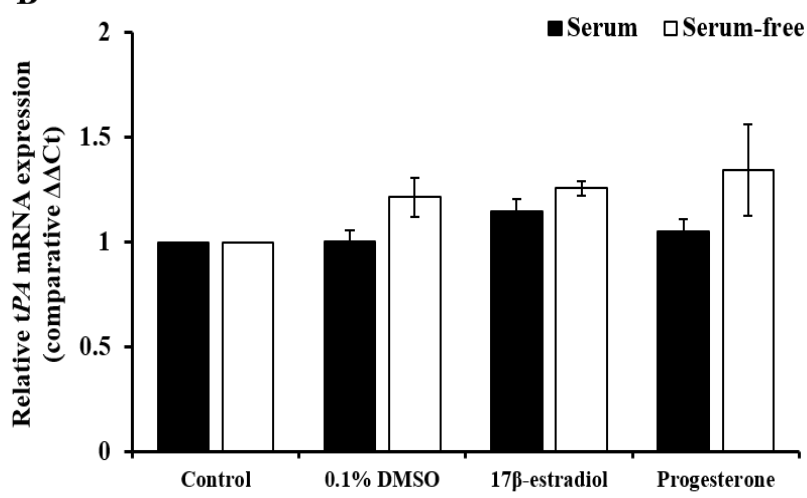

D

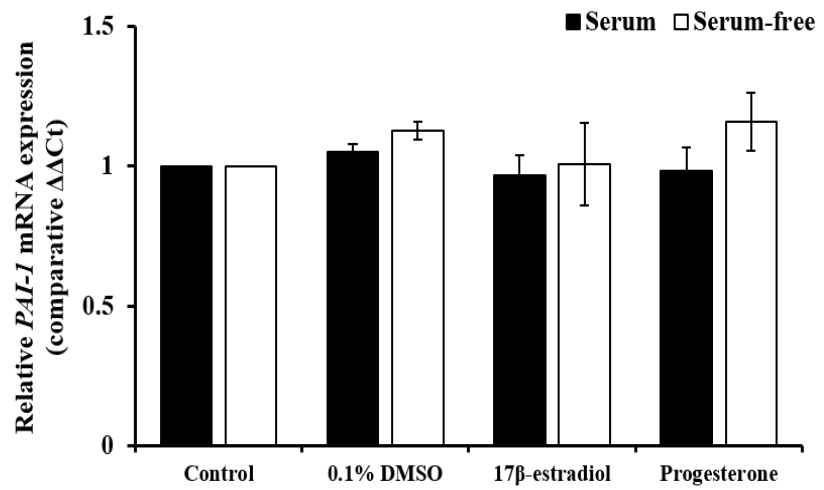

Fig. 1. Changes of two-types of plasminogen activators (Pas: urokinase-type, $u P A$; tissue-type, $t P A$ ), uPA receptor (uPAR), and type-1 PA inhibitor (PAI-1) by $0.1 \%$ dimethyl sulfoxide (DMSO), $20 \mathrm{ng} / \mathrm{mL} \mathrm{17 \beta -estradiol} \mathrm{and}$ progesterone with or without serum in porcine uterine epithelial cells. All data were presented as mean \pm SEM from 4 repeated experiments.

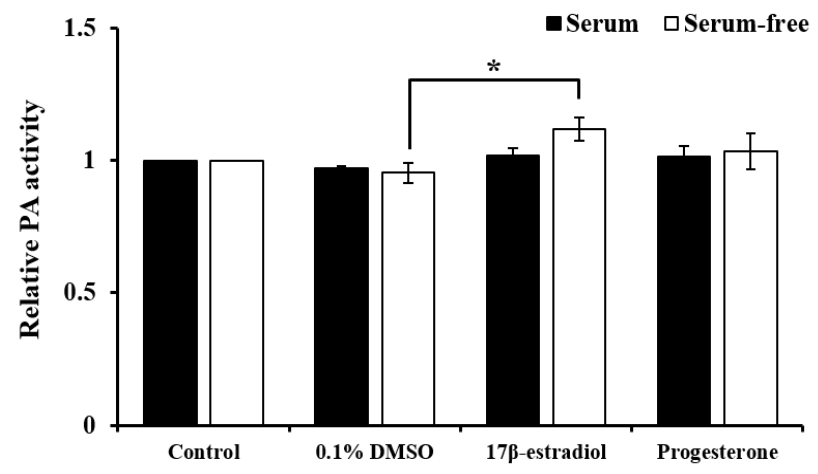

Fig. 2. Changes of plasminogen activators (PAs) by $0.1 \%$ dimethyl sulfoxide (DMSO), $20 \mathrm{ng} / \mathrm{mL}$ $17 \beta$-estradiol and progesterone with or without serum in porcine uterine epithelial cells. Asterisk indicates a significant difference $(p<0.05)$. All data were presented as mean \pm SEM from 4 repeated experiments.
DMSO did not affect to mRNA expression. And treatment of $E_{2}$ enhanced PAs activity compared to control group that was without DMSO treatment $(p<0.05)$.

\section{DISCUSSION}

In mammalians, physiological and morphological features during estrous cycle were altered by various chemokines, cytokines, growth factors, and hormones for successful pregnancy. Cheon (2007) reported that collagen in murine uterus was regulated to induce suitable environment for implantation during early pregnancy. As one of tissue remodeling factors, PAs were existed in porcine uterus and expression of PAs was changed during estrous cycle (Kim et al., 2011). It was involved in reproductive 
A

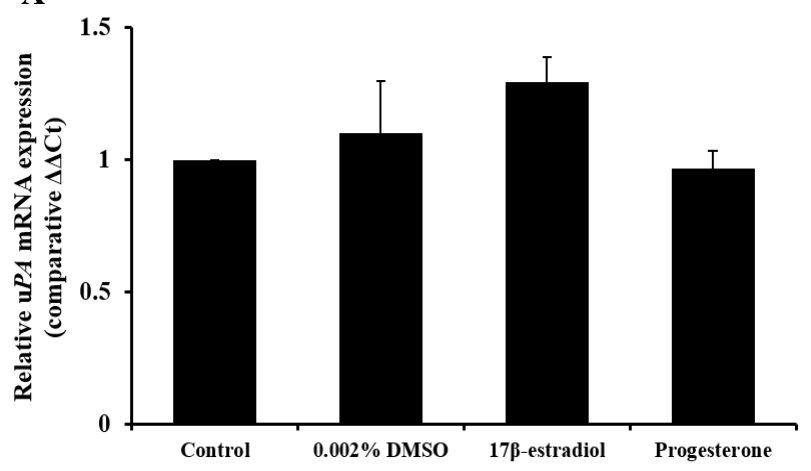

C

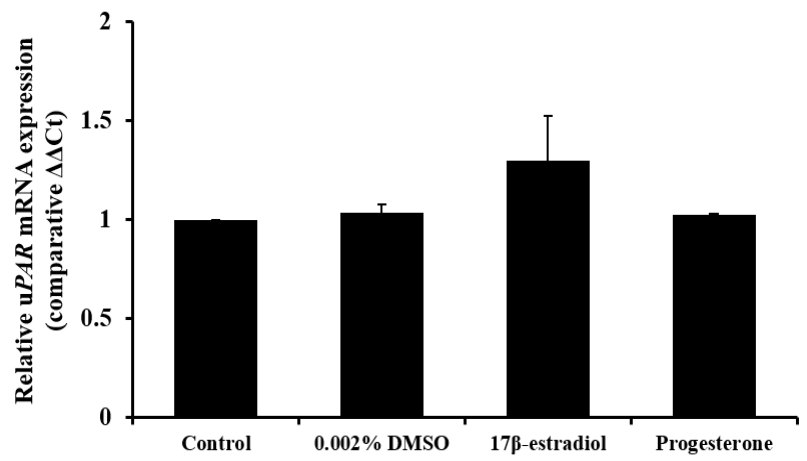

B

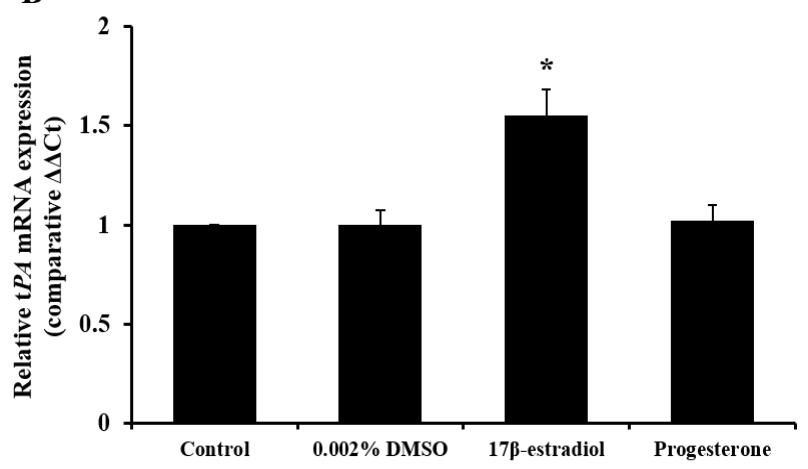

D

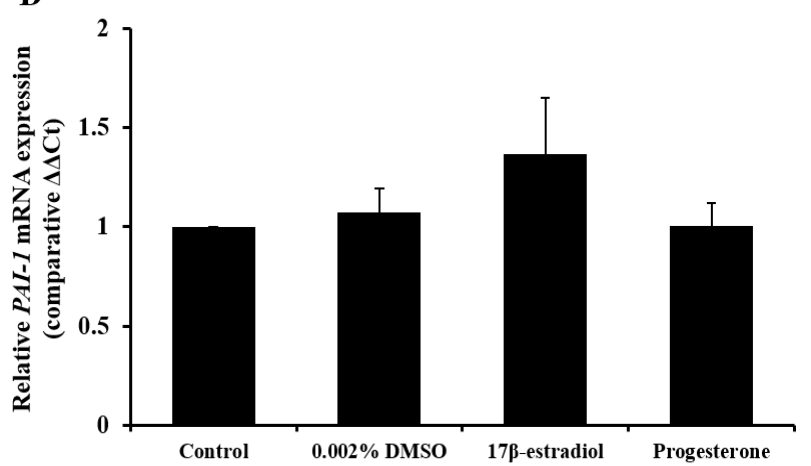

Fig. 3. Changes of two-types of plasminogen activators (PAs; urokinase-type, $u P A$; tissue-type, $t P A$ ), uPA receptor $(U P A R)$, and type-1 PA inhibitor (PAI-1) by $0.002 \%$ dimethyl sulfoxide (DMSO), $20 \mathrm{ng} / \mathrm{mL} 17 \beta$-estradiol and progesterone under serum-free condition in porcine uterine epithelial cells. Asterisk indicates a significant difference $(p<0.05)$. All data were presented as mean \pm SEM from 3 repeated experiments.

and physiological phenomena including degradation of ECM proteins, angiogenesis, ovulation, and oocyte matu-

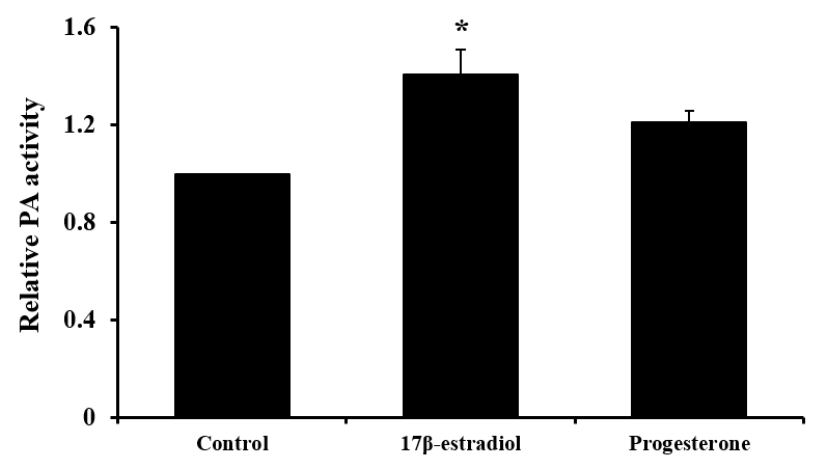

Fig. 4. Changes of plasminogen activators (PAs) by 20 ng/mL 17 $\beta$-estradiol and progesterone under serum-free condition in porcine uterine epithelial cells. Asterisk indicates significant difference $(p<$ 0.05). All data were presented as mean \pm SEM from 5 repeated experiments. ration (Ebisch et al., 2008). Krania et al. (2015) reported that supplementation of tPA during in vitro fertilization of bovine oocytes decreased embryonic development and increased expression of apoptosis-related genes. These demonstrated that PAs are closely associated with reproductive phenomena and play an important role for successful embryo development, fertilization, and pregnancy. Therefore, understanding of expression and regulatory mechanism of PAs in female reproductive tract and cells is crucial.

This study was conducted to confirm effect of steroid hormones on activation of PAs and PAs-related genes expression in pUECs at pre-ovulatory phase. Both of steroid hormones that were diluted with $0.1 \%$ DMSO did not affect to mRNA expression of PAs-related genes regardless of addition of FBS, however, action of hormones was stronger in serum-free condition. The treatment of $E_{2}$, di- 
luted with $0.002 \%$ DMSO, in serum-free medium increased $t P A$ mRNA expression and PAs activity.

Sex steroids including estrogen, $\mathrm{P}_{4}$, and androgen play a crucial roles in function and growth of endometrium (Cheon et al., 2009). During endometrial growth in mice, treatment of estrogen increased the thickness of luminal epithelium, indicating estrogen acted as one of important factors for development of female reproductive tracts (Lai et al., 2000). In addition, action of estrogen in uterus influenced secretion and expression of growth factors, cytokines, and other molecules as well as endometrial development. Estrogen in porcine endometrium regulated the expression of keratinocyte growth factor, ERs, vascular endothelial growth factor (VEGF), and relaxin receptor for successful pregnancy (Ka et al., 2001; Yan et al., 2008). White et al. (2005) had report that osteopontin, important factor for attachment between porcine conceptus and endometrium, in luminal epithelial cells was enhanced by estrogen treatment in pregnant sows and it demonstrated that estrogen derived from porcine conceptus could induce expression of osteopontin in endometrium for successful pregnancy.

$\mathrm{P}_{4}$ is an important sex steroid for maintenance of pregnancy, and it regulate the cellular function and gene expression in variety of cells via interaction with their receptors as well as estrogen (Bazer et al., 2008). The expression of fibroblast growth factor 10 (FGF10) was stimulated by $\mathrm{P}_{4}$ in uterine stromal cells. Secreted FGF from stromal cells induced secretory response and gene expression through activation of phosphoinositide 3-kinase (PI3K) and mitogen activated protein kinase (MAPK) signaling pathway in uterine epithelial cells, and it was involved in cell migration, proliferation, and differentiation of trophoblast cells (Bazer et al., 2008). As mentioned above, action of $\mathrm{P}_{4} \mathrm{de}-$ creased expression of ERs (McCracken et al., 1980).

In present study, PAs activity did not influenced by $\mathrm{P}_{4}$, whereas $E_{2}$ stimulated activation of PAs. In particular, expression of $t P A$ mRNA was increased by $\mathrm{E}_{2}$ treatment.
In porcine oviductal and uterine tissue, PAs activity was higher in pre-ovulatory phase than luteal phase (Ahn et al., 2009; Kim et al., 2011) and these findings suggested that $\mathrm{E}_{2}$ and follicle-stimulating hormone could enhance PAs activity in luminal epithelial cells through increase tPA expression and increased activity might be involved in endometrium development, growth of glandular epithelium, and angiogenesis during estrous cycles in pigs.

Mullins et al. (1980) and Fazleabas et al. (1982) reported that expression, secretion and activation of PAI in porcine uterus were induced by $\mathrm{P}_{4}$. Similar with porcine uterus, administration of $\mathrm{P}_{4}$ increased PAI-1 expression in porcine oviduct tissues (Kouba et al., 2000). However, in this study, $\mathrm{P}_{4}$ did not affect to PAs activation in epithelial cell, whereas $\mathrm{E}_{2}$ stimulated PAs activity. In human, activation of PAs in uterus was regulated by PAI-1 during decidualization of stromal cells, and PAI-1 expression in cultured stromal and decidual cells was increased by progestin (Schatz \& Lockwood, 1993; Schatz et al., 1995). The PRs levels in epithelial cells in ovine uterus was lower than stromal cells and it was increased by stimulation of estrogen (Bazer et al., 2008). Spencer et al. (1995) reported that expression of PRs was reduced by continuous exposure by $\mathrm{P}_{4}$. In pig, physiological concentration of $\mathrm{P}_{4}$ in blood plasma is approximately $1 \mathrm{ng} / \mathrm{mL}$ at pre-ovulatory phase (Noguchi et al., 2010). Therefore, we supposed that $\mathrm{P}_{4}$ did not affect to express and activate of PAs in epithelial cells, because absence of stromal cell and estrogen lead to reduce expression of PRs in epithelial cells and these were caused decreasing of response by $\mathrm{P}_{4}$ stimulation. And high concentration of $\mathrm{P}_{4}$ might decreased PRs level in cells via negative feedback. To investigate effect of $\mathrm{P}_{4}$ on regulation of PAs activity, our futher plan include analysis of expressino of PRs under co-incubation of epithelial and stromal cells, and concentration and treatment time.

The FBS is commonly used to supply nutrients and support survival, divide, and growth of various type of cells. It contains a variety of proteins, growth factors, and several 
undefined factors. In our findings, PAs activity was not affect by both of $\mathrm{E}_{2}$ and $\mathrm{P}_{4}$ under FBS-presence condition. Alpha-2-macroglobulin $(\alpha 2 \mathrm{M})$, one of components in FBS, inhibits several proteases such as plasmin and kallikrein (de Boer et al., 1993). Therefore, because of several protease inhibitors including $\alpha 2 \mathrm{M}$ in FBS, changes of PAs activity by both steroid hormones was not detected. However, more researches are needed whether FBS inhibits function of steroids or action of proteases such as plasmin.

In conclusion, we found that effect of steroid hormones is strongly in serum-free condition than serum condition and PAs activity was enhanced by estrogen, whereas $\mathrm{P}_{4}$ did not affect. The Serum-free condition was proper to measure activity of protease by steroid hormones because various components in FBS could influence to express receptors for hormones and activation of protease. The activation of PAs was increased by treatment of $E_{2}$ via increasing expression of tPA and it may be contribute to uterine development during pre-ovulatory phase in pigs.

\section{ACKNOWLEDGEMENTS}

This work was supported by the National Research Foundation of Korea (NRF) grant funded by the Korea government (Ministry of Education) (2016R1D1A1B03931746).

\section{REFERENCES}

Ahn SH, Cheong HT, Yang BK, Kim DY, Park CK (2009)

Relationship between plasminogen activity and plasminogen inhibitor during the culture of porcine oviduct epithelial cells. Reprod Dev Biol 33:203-209.

Baker VL, Draper M, Paul S, Allerheiligen S, Glant M, Shifren J, Jaffe RB (1998) Reproductive endocrine and endometrial effects of raloxifene hydrochloride, a selective estrogen receptor modulator, in women with regular menstrual cycles. J Clin Endocr Metab 83:6-13.

Bazer FW, Burghardt RC, Johnson GA, Spencer TE, Wu G
(2008) Interferons and progesterone for establishment and maintenance of pregnancy: Interactions among novel cell signaling pathways. Reprod Biol 8:179-211.

Bazer FW, Johnson GA (2014) Pig blastocyst-uterine interactions. Differentiation 87:52-65.

Beers WH (1975) Follicular plasminogen and plasminogen activator and the effect of plasmin on ovarian follicle wall. Cell 6:379-386.

Casslen B, Astedt B (1983) Occurrence of both urokinase and tissue plasminogen activator in the human endometrium. Contraception 28:553-564.

Cheon YP (2007) Altering of collagens in early pregnant mouse uterus. Dev Reprod 11:1-11.

Cheon YP, Lee DM, Chun TH, Lee KH, Choi IH (2009) Androgen in the uterus: A compensator of estrogen and progesterone. Dev Reprod 13:133-143.

Coy P, Jimenez-Movilla M, Garcia-Vazquez FA, Mondejar I, Grullon L, Romar R (2012) Oocytes use the plasminogen-plasmin system to remove supernumerary spermatozoa. Hum Reprod 27:1985-1993.

de Boer JP, Creasey AA, Chang A, Abbink JJ, Roem D, Eerenberg AJ, Hack CE, Taylor FB Jr (1993) Alpha-2macroglobulin functions as an inhibitor of fibrinolytic, clotting, and neutrophilic proteinases in sepsis: studies using a baboon model. Infect Immun 61:5035-5043.

Demir R, Yaba A, Huppertz B (2010) Vasculogenesis and angiogenesis in the endometrium during menstrual cycle and implantation. Acta Histochem 112:203-214.

Ebisch IMW, Thomas CMG, Wetzels AMM, Willemsen WNP, Sweep FCGJ, Steegers-Theunissen RPM (2008) Review of the role of the plasminogen activators system and vascular endothelial growth factor in subfertility. Fertil Steril 90:2340-2350.

Elangovan S, Ramachandran S, Venkatesan N, Ananth S, Gnana-Prakasam JP, Martin PM, Browning DD, Schoenlein PV, Prasad PD, Ganapathy V, Thangaraju M (2011) SIRT1 is essential for oncogenic signaling by estrogen/ estrogen receptor $\alpha$ in breast cancer. Cancer Res 71: 


\section{4-6664.}

Fazleabas AT, Bazer FW, Roberts RM (1982) Purification and properties of a progesterone-induced plasmin/trypsin inhibitor from uterine secretions of pigs and its immunocytochemical localization in the pregnant uterus. J Biol Chem 257:6886-6897.

Finlay TH, Katz J, Kirsch L, Levitz M, Nathoo SA, Seiler S (1983) Estrogen-stimulated uptake of plasminogen by the mouse uterus. Endocrinology 112:856-861.

Franczak A, Wojciechowicz B, Kotwica G (2013) Transcriptomic analysis of the porcine endometrium during early pregnancy and the estrous cycle. Reprod Biol 13: 229-237.

Gray CA, Bartol FF, Tarleton BJ, Wiley AA, Johnson GA, Bazer FW, Spencer TE (2001) Developmental biology of uterine glands. Biol Reprod 65:1311-1323.

Hwangbo Y, Lee SH, Cha HJ, Song EJ, Lee ST, Lee ES, Cheong HT, Yang BK, Park CK (2013) Expression of plasminogen activators in uterine epithelial cells of preovulatory phase in pigs. J Embryo Transf 28:257-263.

Ka H, Jaeger LA, Johnson GA, Spencer TE, Bazer FW (2001) Keratinocyte growth factor is up-regulated by estrogen in the porcine uterine endometrium and functions in trophectoderm cell proliferation and differentiation. Endocrinology 142:2303-2310.

Kim KH, Lee YS, Gu HN, Yang BK, Cheong HT, Park CK (2011) Changes in plasminogen activity in uterus tissue during the estrous cycle in the pigs. Reprod Dev Biol 35:463-468.

Kobayashi T, Matsuda Y, Park JY, Hara I, Kaneko S, Fujimoto Y, Nozawa S, Akihama S (1992) Trypsin-like arginine amidases including plasminogen and plasmin in human seminal plasma by affinity adsorption and elution. Arch Androl 28:165-170.

Kouba AJ, Burkhardt BR, Alvarez IM, Goodenow MM, Buhi WC (2000) Oviductal plasminogen activator inhibitor-1 (PAI-1): mRNA, protein, and hormonal regulation during the estrous cycle and early pregnancy in the pig. Mol Reprod Dev 56:378-386.

Krania F, Dovolou E, Rekkas CA, Theodosiadou EK, Pappas I, Amiridis GS (2015) Effects of addition of tissuetype plasminogen activator in in vitro fertilization medium on bovine embryo development and quality. Reprod Domest Anim 50:112-120.

Lai MD, Lee LR, Cheng KS, Wing LYC (2000) Expression of proliferating cell nuclear antigen in luminal epithelium during the growth and regression of rat uterus. J Endocrinol 166:87-93.

Martin O, Arias F (1982) Plasminogen activator production by trophoblast cells in vitro: Effect of steroid hormones and protein synthesis inhibitors. Am J Obstet Gynecol 142:402-409.

McCracken JA (1980) Hormone receptor control of prostaglandin $F_{2}$ alpha secretion by the ovine uterus. Adv Prostaglandin Thromboxane Res 8:1329-1344.

Menshikov M, Plekhanova O, Cai H, Chalupsky K, Parfyonova Y, Bashtrikov P, Tkachuk V, Berk BC (2006) Urokinase plasminogen activator stimulates vascular smooth muscle cell proliferation via redox-dependent pathways. Arter Thromb Vasc Biol 26:801-807.

Mullins DE, Bazer FW, Roberts RM (1980) Secretion of a progesterone-induced inhibitor of plasminogen activator by the porcine uterus. Cell 20:865-872.

Noguchi M, Yoshioka K, Itoh S, Suzuki C, Arai S, Wada Y, Hasegawa Y, Kaneko H (2010) Peripheral concentrations of inhibin A, ovarian steroids, and gonadotropins associated with follicular development throughout the estrous cycle of the sow. Reproduction 139:153-161.

Olofsson B, Korpelainen E, Pepper MS, Mandriota SJ, Aase K, Kumar V, Gunji Y, Jeltsch MM, Shibuya M, Alitalo K, Eriksson U (1998) Vascular endothelial growth factor B (VEGF-B) binds to VEGF receptor-1 and regulates plasminogen activator activity in endothelial cells. Proc Natl Acad Sci USA 95:11709-11714.

Ploplis VA, French EL, Carmeliet P, Collen D, Plow EF (1998) Plasminogen deficiency differentially affects 
recruitment of inflammatory cell populations in mice. Blood 91:2005-2009.

Sappino AP, Huarte J, Belin D, Vassalli JD (1989) Plasminogen activators in tissue remodeling and invasion: mRNA localization in mouse ovaries and implanting embryos. J Cell Biol 109:2471-2479.

Schatz F, Aigner S, Papp C, Toth-Pal E, Hausknecht V, Lockwood CJ (1995) Plasminogen activator activity during decidualization of human endometrial stromal cells is regulated by plasminogen activator inhibitor 1 . J Clin Endocrinol Metab 80:2504-2510.

Schatz F, Lockwood CJ (1993) Progestin regulation of plasminogen activator inhibitor type 1 in primary cultures of endometrial stromal and decidual cells. J Clin Endocrinol Metab 77:621-625.

Spencer TE, Bazer FW (2002) Biology of progesterone action during pregnancy recognition and maintenance of pregnancy. Front Biosci 7:1879-1898.

Spencer TE, Becker WC, George P, Mirando MA, Ogle TF, Bazer FW (1995) Ovine interferon-tau regulates expression of endometrial receptors for estrogen and oxytocin but not progesterone. Biol Reprod 53:732-745.
Spencer TE, Johnson GA, Burghardt RC, Bazer FW (2004) Progesterone and placental hormone actions on the uterus: Insights from domestic animals. Biol Reprod 71:210.

Stroband HWJ, Taverne, N, Langenfeld K, Barends PMG (1986) The ultrastructure of the uterine epithelium of the pig during the estrous cycle and early pregnancy. Cell Tissue Res 246:81-89.

Tanikawa M, Kim TS, Okuda K, Ryoo ZY, Park SB, Shin JH, Park CK, Lee DS (2009) Cell-type specificity of interleukins $1 \alpha$ and $1 \beta$ on prostaglandin and plasminogen activator production in bovine endometrial cell. Anim Reprod Sci 114:32-42.

White FJ, Ross JW, Joyce MM, Geisert RD, Burghardt RC, Johnson GA (2005) Steroid regulation of cell specific secreted phosphoprotein 1 (osteopontin) expression in the pregnant porcine uterus. Biol Reprod 73:1294-1301.

Yan W, Chen J, Wiley AA, Crean-Harris BD, Bartol FF, Bagnell CA (2008) Relaxin (RLX) and estrogen affect estrogen receptor $\alpha$, vascular endothelial growth factor, and RLX receptor expression in the neonatal porcine uterus and cervix. Reproduction 135:705-712. 